\title{
Korstog og islam i gymnasiet: Historien om tilblivelsen af en undervis- ningsbog
}

Af Lars Peter Visti Hansen

Resumé

Korstog, kulturmøder og interessen for den muslimske verden står i dag mere centralt i gymnasiet end tidligere. Men mens islam er obligatorisk stof i religionsundervisningen, behandles den muslimske verdens historie kun kortfattet i de historiske lærebøger. Efter gymnasiereformens indførelse i 2005, står begrebet kulturmøde centralt i historiebekendtgørelsen, men det er et begreb, der kan komme til at betone modsætninger, snarere end de fællestræk, der mellem vesten og den muslimske verden. Det afspejler sig delvist i det udbud af læremateriale, der har været til rådighed i gymnasiet. Det er i den sammenhæng, at lærebogen Korstogene Idé og Virkelighed er blevet til. Bogen behandler korstogene og vil samtidig gerne give læserne et mere solidt indblik i den muslimske verdens historie.

\section{Baggrunden for Korstogene - idé og virkelighed}

I foråret 2002 sendte jeg, efter at have brugt et par år på at læse mig ind på emnet, et forslag til en ny undervisningsbog til gymnasiet og HF om korstogene til forlaget Systime. Det var der flere grunde til. Jeg havde på universitet arbejdet en del med europæisk middelalder og ved forskellige lejligheder hjulpet kolleger, der var ved at udgive undervisningsmateriale. På den måde fik jeg lyst til at prøve mig selv af som lærebogsforfatter. Jeg havde flere gange klippet og klistret forløb sammen om korstogene, uden at være særlig tilfreds med hvad jeg kunne grave frem. I den proces fik jeg læst en række bøger om korstogene og også læst mig ind på nyere bøger om islam og Vesten, indtil jeg til sidst mente, at jeg kunne lave en bog, der a) var bedre end det, der forelå, b) tog den muslimske verdens rolle i korstogene alvorligt, og c) fulgte korstogene helt op til vores tid.

Det var et personligt projekt til at begynde med, men i takt med min egen voksende interesse for den muslimske verden opdagede jeg, at det modsvarede en generelt voksende interesse hos korstogsinteresserede og elever i al almindelighed. Korstogene kunne på den måde forhåbentlig være en "port" til en bredere forståelse af den muslimske verden og dens forhold til Vesten.

Da Korstogene - Idé og virkelighed udkom i december 2004 var historieundervisningen i gymnasiet og på HF ved at ændre sig som følge af gymnasie- og HF-reformerne, der blev indført for de nye elever i sommeren 2005. Faget historie har fået mindre tid end før reformen, mens der til gengæld er områder, der skal behandles. Selv om der på den måde er blevet mindre tid til fordybelse i det enkelte emne, er middelalderens kulturmøde mel- 
lem den kristne og den muslimske verden blevet obligatorisk kernestof i gymnasiet. Det har betydet, at korstogene i dag er et mere populært emne end tidligere.

\section{Undervisningsmateriale om korstogene}

Korstogene bliver kortfattet beskrevet som fremstillingsstof i en lang række verdenshistorier til brug i gymnasiet. I nyere verdenshistorier er tendensen, at korstogene er mere $\mathrm{i}$ fokus end tidligere, og at korstogene derfor også optager mere plads i bøgerne. I den meget anvendte verdenshistorie Menneske Samfund Historie (Mogens Carstensen et al., Gyldendal 1989) fylder korstogene f.eks. samlet set mindre end en side. I Grundbog til Historie (Peter Frederiksen et al., Systime 2000) indgår korstogene som et samlet emne med kilder og fylder ca. 17 sider.

Det er sværere at finde emnebøger om korstogene, der går i dybden med stoffet, og som har kildemateriale med. De bøger, det er lykkedes mig at finde, er alle udkommet inden for de sidste 20 år. I 1988 kom Gud vil det af Johnny Thiedecke. Den er senere kommet i en ny udgave i 1999 med titlen Hellig Krig. Thiedecke er en af de flittigste forfattere i den danske gymnasieverden, og hans bøger er ofte udmærkede kildesamlinger til de perioder, de behandler. Kilderne i Gud vil det lægger op til at eleverne selv arbejder med kildeuddragene, men der er til gengæld meget lidt fremstillingsstof. Kildernes omfang og den sparsomme indføring kan virke uoverskuelig for gymnasie- og HF-eleverne i dag. Bogen kræver, efter min mening, at man inddrager supplerende fremstillingsmateriale.

I 1998 udkom Henrik Skovgaard Nielsens Korstog og Jihad - kulturmøder mellem Europa og islam ca. 600- ca. 2000. Det er en meget, og måske også for, ambitiøs bog, der på ca. 90 sider kommer omkring islams historie, korstogene, Osmannerriget, nutidens Tyrkiet, orientalisme og indvandring til den vestlige verden i dag. Desuden indeholder bogen kildemateriale, der lægger op til en diskussion af forholdet mellem "os" og "de andre". Korstogene som sådan fylder blot 12 sider i bogen. Bogen lever på mange måder op til kravene i den nye gymnasiereform, og bruges flittigt i gymnasieskolen og på HF. Da bogen kom frem, var indvandringen af muslimer til Vesten blevet et politisk omdiskuteret emne, og det er også der, bogen lægger sit fokus i de sidste kapitler.

Alt $\mathrm{i}$ alt fandtes der altså materiale om korstogene, men enten var emnet overfladisk dækket, ikke bundet sammen til en helhed, eller også var korstogene ikke egentlig i fo- 
kus. Det var de mangler, jeg gerne ville rette op på. Begivenhederne 11/9 2001 fik samtidigt interessen for forholdet mellem Vesten og den muslimske verden til at vokse voldsomt.. Historisk set er det oplagt at søge tilbage og se på hellige og retfærdige krige, og tidligere konfrontationer mellem "Østen" og "Vesten". Korstogene er også kommet i fokus populært gennem f.eks. Ridley Scotts korstogsfilm Kingdom of Heaven eller Jan Guillous Arn-bøger.

\section{Undervisningsmateriale om Islam og den muslimske verden}

Når man ser bort fra korstogene, det muslimske Spanien, Israel-Palæstina konflikten, Golf-krigene og til dels Osmannerriget, fylder den muslimske verdens historie ikke ret meget i historieundervisningen i gymnasiet, i modsætning til islam som religion, der er et fast indslag i religionsundervisningen. Munksgaard udgav i 1987 grundbogen Verden uden for Europa, der indeholder nogle velskrevne kapitler om den muslimske verdens historie af Jørgen Bæk Simonsen, men det er, så vidt vides, ikke en bog, der er blevet anvendt ret flittigt, i modsætning til den bog den dannede par med; Europas verdenshistorie. Peter Seeberg har skrevet bogen Det moderne Mellemøsten, der er spændende, men også relativ svær læsning for eleverne, selv på de sidste trin. I Spanien Anderledes, en historiebog til klasser med spansk som studieretningsfag, beskrives den iberiske halvøs muslimske fortid i et par kapitler.

Udover det egentlige undervisningsmateriale anvendes der ofte kopieret materiale fra f.eks. Nationalmuseets katalog til udstillingen Sultan, Shah og Stormogul og tidsskrifter som Sfinx, der fungerer fint på gymnasieniveau.

En række religionsbøger om islam har også historiske indføringer til islam, men de er som regel temmelig kortfattede og vægter ikke historien nær så højt som de religiøse aspekter af islam. En undtagelse er Jakob Skovgaard Petersens bog Moderne Islam med en række fine afsnit om Egyptens historie fra 1517 til i dag, der sagtens kan anvendes i historieundervisningen i gymnasiet og på HF. Alt i alt er det historiske kendskab til den muslimske verden ikke ret stort, og der er også meget lidt materiale til undervisningsbrug, der giver lærere og elever muligheden for at få et nuanceret billede af den muslimske verdens historie. 


\section{Tilblivelsen af Korstogene Idé og virkelighed}

Da jeg gik i gang med at skrive Korstogene Idé og virkelighed havde jeg en idé om, hvad en 'rigtig' undervisningsbog om korstog skulle indeholde. Først og fremmest skulle bogen forklare, hvad korstog er for et fænomen, dvs. forklare pilgrimstogter, bod, aflad, hellig- og retfærdig krig, og hvordan det bliver vigtige komponenter i korstogene. Det kan være svært at forstå for eleverne, og det er også mere kompliceret, end det lyder, fordi der blandt forskerne ikke er enighed om en definition. Tidligere har tendensen inden for korstogsforskningen været, at betragte korstogene til Mellemøsten som de eneste rigtige korstog, men i de sidste 20-30 år er definitionen af korstog blevet bredt ud til også at omfatte korstog i Østeuropa, på den Iberiske halvø, og "indre" korstog som f.eks. kætterkorstogene. Denne nye definition gælder også for Korstogene Idé og virkelighed, selv om de første korstog til Mellemøsten stadig har en særlig fremtrædende plads.

Dernæst skulle bogen give et billede af den del af verden, hvor korstogene begyndte sidst i 1000-tallet, dvs. det vestlige Europa, og de steder, der blev påvirket af korstogene til Mellemøsten, dvs. den muslimske verden og Byzans (det østromerske rige). Bogen skulle gerne råde bod på, at Byzans’ og den muslimske verdens historie op til o. 1100 ikke tidligere er beskrevet særlig indgående i lærebogsmateriele til gymnasiet. Alt i alt skulle læseren gerne få en fornemmelse for disse tre dele af verden, og den måde de påvirkede hinanden på.

Den vigtigste opgave for bogen var at få formidlet den gode historie, som korstogene også er, til læseren/eleven i en blanding af fremstillingsafsnit og kildemateriale. Det er vistnok lykkedes uden at gøre korsfarerne til "Guds Galninge", eller deres modstandere til uskyldige ofre eller onde jihadister. Korstogene har som emne den fordel, at der findes et righoldigt og spændende kildemateriale at vælge fra, både fra vestlige, muslimske og byzantinske kilder. Det er på den måde relativt nemt at stille kilder op overfor hinanden, der ser på den samme begivenhed fra forskelligt perspektiv.

Det var altså vigtigt, at bogen skulle vægte både kristne og muslimske kilder og forklare udviklingen i både Europa og Mellemøsten før og under korstogene. Det kan synes banalt, men i en lang række, også nyere, bøger om korstogene behandles den muslimske verden kun yderst nødtørftigt, som et nødvendigt bagtæppe for de vestlige kristnes udfoldelser. Jeg synes, det var væsentligt at forklare, hvordan den politiske udvikling i den 
muslimske verden på den ene side gjorde det første korstogs succes mulig, og samtidig hvordan magtkampene mellem og blandt seldsjukker, fatimider, ayubider osv. var helt afgørende for udviklingen i korsfarerstaterne.

Det, at man bevæger sig hen imod en mere global synsvinkel, der er mindre fokuseret på den vestlige verden, kendes fra andre undervisningsbøger. For eksempel havde det tidligere mest anvendte hæfte om Vietnamkrigen fra 1980'erne undertitlen "USAs krig i Vietnam", mens den nyeste bog (fra o. 2000) har titlen "Vietnam fra drage til tiger", og den handler faktisk også om landet Vietnam.

Bogens sidste kapitler er helliget synet på korstogene op til i dag og forskellige vurderinger af korstogene. Skulle bogen revideres i dag ville den del få en endnu mere fremtrædende placering, fordi korstogene stadig diskuteres ivrigt. Korstogene 'læses' jo i dag på baggrund af 9/11, terror, indvandring, computerspil m.m., og det er vigtigt at vise, at korstogene har været og fortsat bliver brugt politisk til at anskue verden og retfærdiggøre nutidige mål. Her er der, fra et skolesynspunkt, god mulighed for at tage en række kritiske spørgsmål op i klasseværelset: Var korsfarerne "Guds galninge” eller oprigtigt troende? Var korstogene en del af "civilisationernes sammenstød"? Hvad er forskellen på kristen hellig krig og jihad? Var korstogene en kristen forsvarskrig? Er nutidens muslimske indvandring en 3. jihad? Ødelagde korstogene forholdet mellem kristne og muslimer i Mellemøsten? Er Israel en moderne korsfarerstat? Er USA's (og Danmarks) krig i Irak et moderne korstog? Oftest stilles spørgsmålene for at retfærdiggøre et nutidigt politisk formål. For elever og andre, der skal forsøge at forholde sig til dem, er det vigtigt, at man i det mindste ved, hvad korstogene gik ud på.

\section{Gymnasiereformen, korstog og kulturmøder}

Efter gymnasiereformen er begrebet "kulturmøde" blevet centralt i bekendtgørelsen for faget historie. Det bruges om middelalderens kulturmøde mellem kristendom og islam, og senere også i forbindelse med kolonitid og europæisk imperialisme.

"Kulturmøde" anvendes i bekendtgørelsen uden nogen nærmere definition i sammenhæng med europæisk ekspansion og dominans. Det er på den ene side positivt, at eleverne kommer til at beskæftige sig med fremmede kulturer, men sådan som det bruges i bekendtgørelsen, er det problematisk, at man samtidig skaber et billede af to (eller flere) 
grundlæggende forskellige kulturer. I forbindelse med middelalderens kulturmøde skaber det et fokus på modsætningen mellem det kristne Europa og den muslimske verden, snarere end på de fællestræk og fælles rødder, der også er, f.eks. i den antikke middelhavsverden. Det problem, mener jeg, stiller særlige krav til lærerens evne til at formidle et mere differentieret billede af virkeligheden end begrebet "kulturmøde" i første omgang lægger op til. I undervisningssammenhæng er der f.eks., også før reformen, skrevet langt mere om konfrontation og korstog end om f.eks. den videnskabelige indflydelse, der kom fra den muslimske verden $\mathrm{i}$ århundrederne inden renæssancen.

Korstogene er blevet et godt undervisningsemne i gymnasiet og på HF i dag, dels fordi bekendtgørelsen lægger op til det, dels fordi man med udgangspunkt i korstogene kan diskutere forholdet mellem Vesten og den muslimske verden i dag. På HF glider emnet også naturligt ind i det nye kultur- og samfundsfagsgruppe, hvor samfundsfag, religion og historie har en fælles afsluttende eksamen.

Ved at kigge på de studieplaner, der ligger offentligt tilgængelige på gymnasiernes hjemmesider, er det mit indtryk, at nogle af de afsnit i Korstogene idé og virkelighed, der bruges flittigst, netop er afsnittene om korstogene i eftertiden og synet på korstogene i dag, fordi de naturligt lægger op til en diskussion i klassen. Man læser sjældent om korstog for udelukkende at få indsigt i middelalderens verden. Koblingen til nutiden er helt central. Derfor kan der også ofte være en pointe i at inddrage og kritisk diskutere nyere avisartikler om korstogene. Til gengæld er det nok de færreste, der når igennem hele bogen, fordi tiden efter reformerne er blevet knap. Forhåbentlig bidrager diskussionerne med udgangspunkt i middelalderens korstog til at øge kendskabet til den muslimske verdens historie både før og nu.

\section{Litteratur}

Carstensen, Mogens et al., 1989: Menneske Samfund Historie, Gyldendal, København.

Essinger, Bent et al., 1987: Verden uden for Europa, Munksgaard, København.

Folsach, Kjeld von et al, 1996: Sultan, Shah og Stormogul, Nationalmuseet, København.

Frederiksen, Peter et al., 2000: Grundbog til historie - verdenshistorien indtil 1750, Systime, Århus 
Hansen, Lars Peter Visti, 2007: "Kristendom og Islam - middelalderens kulturmøde", i Fokus 1 - fra Antikken til Rencessancen, (red: Ulrik Grubb et al.) Gyldendal, København.

- 2004: Korstogene. Idé og virkelighed. Systime, Århus.

Jensen, Anker Leo, 2005: Spanien Anderledes, Gyldendal, København.

Jeppesen, Lene \& Peter Seeberg, 1998: Mellem øst og vest - Fra Osmannerriget til det moderne Tyrkiet, Munksgaard, København.

Marstal, Poul et al., 1970: Gjellerups Verdenshistorie grundbog 1. oldtid-1650, Gjellerup

Mentz, Jørgen, 1994: Krudtimperierne - Osmanner, Safavider, Moguler 1500-1700, Systime, Århus

Nielsen, Torben K., 2005: "Anmeldelse af Korstogene Idé og virkelighed", www.historie-online.dk

Seeberg, Peter, 2005: Det moderne Mellemøsten, Gyldendal, København.

Nielsen, Henrik Skovgaard, 1998: Korstog og jihad? Gad, København.

Petersen, Jakob Skovgaard, 1995: Moderne Islam, Gyldendal Uddannelse

Thiedecke, Johnny, 1999: Hellig Krig, Pantheon.

- 1988: Gud vil det, Forlaget Marko

Lars Peter Visti Hansen, født 1966, er gymnasielektor i engelsk og historie. Han er forfatter til Korstogene idé og virkelighed (Systime 2004) og "Kristendom og islam - middelalderens kulturmøde" i Fra antikken til reformationen (red: Ulrik Grubb et al., Gyldendal uddannelse 2007). 